\title{
Lost revenues associated with going concern modified opinions in the Swedish audit market
}

\author{
Jan Svanberg and Peter Öhman \\ Department of Business, Economics and Law, \\ Centre for Research on Economic Relations, Mid Sweden University, \\ Sundsvall, Sweden
}

\begin{abstract}
Purpose - The purpose of this paper is to examine the costs to audit firms in terms of lost revenues of losing small clients due to auditor switching or client bankruptcy after issuing first-time going concern modified opinions.

Design/methodology/approach - A population of small Swedish companies receiving first-time going concern modified opinions in 2009 was examined to determine the effects two years later compared with a matched sample of financially stressed companies that had not received going concern modified opinions.

Findings - The results indicate that both auditor switching and client bankruptcy are positively related to receipt of going concern modified opinions. Furthermore, the authors find empirical evidence that auditors issuing first-time going concern modified opinions lose proportionately more fees through auditor switching and client bankruptcy than do auditors not issuing such opinions to financially stressed clients. Finally, the authors found that the going concern modified opinions issued by Big 4 firms are no more harmful to clients than are those issued by other audit firms.

Research limitations/implications - The authors recognize a limitation of this study regarding the choice of control companies. Although the authors attempted to find similarly sized and similarly financially stressed companies from the same industries as those companies in the test group, the authors may have missed other variables relevant to auditor switching or client bankruptcy. Practical implications - A practical implication for the audit profession is the increased awareness of the fact that the financial dependence issues reported in this study extend to auditors with small client companies.

Originality/value - This is the first study to examine fees lost due to auditor switching and client bankruptcy caused by going concern modified opinions in a population of small companies. It contributes to the mixed evidence presented in previous research as to the extent to which going concern modified audit opinions are self-fulfilling prophecies.
\end{abstract}

Keywords Bankruptcy, Audit report, Auditor switching, Financial dependence,

Going concern modified opinion

Paper type Research paper

\section{Introduction}

Though the causes are unclear, research has demonstrated that auditors seldom issue going concern modified opinions (GCM opinions) before bankruptcies (e.g. Citron and Taffler, 1992; Knechel and Vanstraelen, 2007). This auditor reticence may be due to either strong relationships with clients or an inability to identify the risk of client bankruptcy (Ruiz-Barbadillo et al., 2004; Blay et al., 2011). When the auditor is influenced by the relationship with the client, this relationship is usually regarded as one of financial dependence (Umar and Anandarajan, 2004; Bamber and Iyer, 2007). While it is generally suggested that financial dependence does exist, the extent to which an auditor is actually punished through loss of revenue due to auditor switching

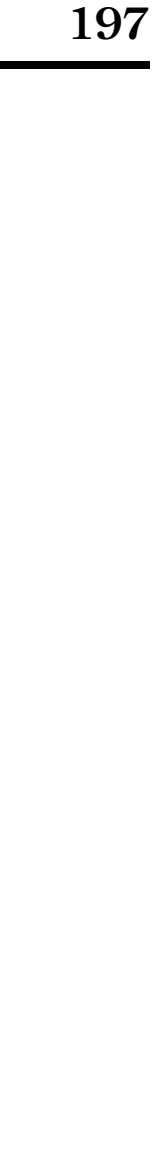

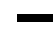

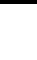


JAAR

15,2

198 is still debated. Auditors claim that they risk being replaced by disappointed clients if they issue what the clients consider unwarranted GCM opinions (Geiger et al., 1998; Carcello and Neal, 2003; Carey et al., 2008), and recent evidence suggests that future audit and non-audit fees discourage auditors from issuing GCM opinions (Blay and Geiger, 2013). Auditors may also want to avoid situations in which they are causing client bankruptcy by issuing their GCM opinions (Citron and Taffler, 1992; Louwers et al., 1999).

Prior evidence as to the effects of the issuance of GCM opinions concerns both sides of the coin: the loss of auditor revenue due to auditor switching and the increased probability of client bankruptcy. Research (e.g. Garsombke and Choi, 1992; Geiger et al., 1998; Louwers et al., 1999; Carcello and Neal, 2003) has reported a higher switching rate post-GCM opinions, but there is mixed evidence regarding GCM opinions as self-fulfilling prophecies. To our knowledge, only one study (Carey et al., 2008) has investigated lost fees as a direct measure of the effects on the audit firm of auditor switching or client bankruptcy. Carey et al. (2008) demonstrated a positive relationship between GCM opinions, auditor switching, and lost fees, but the picture was less clear regarding client bankruptcy.

Prior studies conducted in the USA and Australia have focussed on relatively large client companies. The present study extends this prior research to a European - i.e. Swedish - audit market, and also extends previous studies concerning large companies to a sample of small companies. To our knowledge, there is no evidence from the European audit market of lost fees as an effect of GCM opinions, and no evidence indicating that financial dependence may be caused by auditors' relationships with small clients.

We investigate the impact of the issuance of first-time GCM opinions on the probabilities of auditor switching and client bankruptcy. We aim to demonstrate whether a relationship exists between the issuance of first-time GCM opinions, auditor switching, client bankruptcy, and lost fees as a result of auditor switching or client bankruptcy. The present study supplies new evidence by assessing lost fees as a measure of the cost in lost revenue to the audit firm of losing a small client due to auditor switching or client bankruptcy after a first-time GCM opinion, and it contributes to the inconclusive literature on the self-fulfilling prophecy phenomenon.

The remainder of the paper is structured as follows. In the next section we present the theoretical framework, followed by the hypotheses. We then outline the research method and sample selection. This is followed by the findings, and the discussion concludes the paper.

\section{Literature review}

\section{Going concern reporting errors}

Auditors can make two types of errors concerning a GCM opinion. They can either issue a GCM opinion for a company that remains viable or they can neglect or fail to report a GCM opinion for a company that becomes bankrupt within a year. Prior research has established that the first type of error is a type I error and the second a type II error (Hopwood et al., 1989; McKeown et al., 1991). Although both types of errors may have serious consequences, it should be clear that neither type of error refers to a true auditor mistake, because auditors are not required to perfectly predict the future (Carey et al., 2008).

Both types of misclassifications have been thoroughly researched, and clear evidence indicates the difficulty auditors seem to have in correctly assessing financial 
situations that lead to bankruptcy (Louwers et al., 1999; Humphrey, 2008; Rosman, 2011). Among the studies reporting frequent type II errors there is near unanimity that most bankrupt companies never receive a GCM opinion in prior audit reports (e.g. Mutchler, 1984; Hopwood et al., 1989; McKeown et al., 1991; Mutchler et al., 1997; Vanstraelen, 1999; Geiger and Raghunandan, 2002; Van Peursem and Pratt, 2002; Geiger et al., 2005; Van Peursem et al., 2005; Herbohn et al., 2007; Knechel and Vanstraelen, 2007). This striking evidence has attracted much attention in the debate about auditors' GCM opinions. A recent study notes that the issuance of GCM opinions became more frequent from 2000 to 2010 in the USA (Carson et al., 2013), an increase that has slightly modified the picture of GCM opinion accuracy. However, the opposite type of error has not received the same attention, although type I errors appear to be as common at around 80 percent (Mutchler and Williams, 1990; Citron and Taffler, 1992; Garsombke and Choi, 1992; Nogler, 1995; Geiger et al., 1998; Humphrey, 2008).

\section{Clients switching auditors}

Auditor-client contracting entails various influences on the auditor, including fee pressure, making a completely objective audit opinion unlikely (Arnold et al., 2001; Umar and Anandarajan, 2004). For example, audit firm tenure is found to be a factor associated with clients' awarding non-audit services to their current auditors, and audit engagement partner tenure negatively affects the propensity to issue GCM opinions (Ye et al., 2011). According to Nogler (2004), fee pressure motivates auditors to neglect to report client financial problems. Several studies have investigated the effect of GCM opinions on auditor switching (Menon and Schwartz, 1987; Craswell, 1988; Johnson and Lys, 1990; Defond, 1992; Krishnan, 1994; Krishnan and Stephens, 1995; Tucker et al., 2003), but they have not considered whether the companies that received the GCM opinions remained viable or went bankrupt.

Although the possibility of losing clients as a result of issuing GCM opinions has been recognized (Kida, 1980; Chen and Church, 1992; Lennox, 2000; Vanstraelen, 2003), few studies have reported evidence as to the real losses that auditors suffer relating to GCM opinions. Carey et al. (2008) studied lost revenues due to type I misclassifications, and found that Australian auditors lost more clients through auditor switching after issuing GCM opinions. The authors also found that auditors who issued GCM opinions lost more revenues due to auditor switching than did auditors who did not issue GCM opinions in corresponding situations. Other evidence is from the USA, where Geiger et al. (1998) found that auditor switching increased after GCM opinions that turned out to be type I misclassifications, and Carcello and Neal (2003) found a weak relationship between GCM opinions and auditor switching. However, no evidence of how much revenues the auditors lost is available from US studies.

\section{Clients going bankrupt}

If a client does not switch auditors after a GCM opinion, the client may be lost anyway if the client goes bankrupt. According to interviews conducted by Mutchler (1984), six of 16 auditors agreed that the "self-fulfilling prophecy" effect exists, and Garsombke and Choi (1992) and Geiger et al. (1998) reported higher failure rates among companies the year after issuance of GCM opinions. However, there is inconclusive evidence as to whether GCM opinions have a self-fulfilling prophecy effect. On the one hand, some studies find support for the self-fulfilling prophecy effect (Tucker et al., 2003; Vanstraelen, 2003; Nogler, 2004); on the other hand, Carey et al. (2008) reported no such increase in bankruptcy following GCM opinion issuance. In the same vein,

\section{9}


JAAR

15,2

200
Citron and Taffler (1992) reported no increase in bankruptcy among companies in the UK receiving GCM opinions, based on analyzing a matched sample of financially stressed companies that had not received a GCM opinion.

It remains unclear whether the GCM opinion in itself contributes to increasing the likelihood of client bankruptcy. The proponents of this effect claim that the GCM opinion signals a negative view of the company's future viability to financial statement consumers (Menon and Schwartz, 1987; Menon and Williams, 2010), making suppliers, customers, and resource providers more reluctant to do business with the company (Mutchler, 1984, 1985). However, the effect appears to be weak if it exists at all, and the existence of the effect has only been reported by researchers not using a matched sample technique.

\section{Research hypotheses}

GCM opinions, auditor switching, and lost revenue

Auditors may avoid issuing GCM opinions due to the risk of lost future revenues (Blay and Geiger, 2013), and an equally important issue is to what extent clients switch auditors after receiving such opinions. The risk of auditor switching described by Krishnan et al. (1996) was confirmed by Carey et al. (2008). This issue is particularly important to companies receiving GCM opinions for the first time. Clients who have previously received GCM opinions do not react as strongly (Kida, 1980), and the frequency of auditor switching is lower when the GCM opinion is preceded by other such opinions (Carey et al., 2008). In line with this, Geiger et al. (1998) and Carcello and Neal (2003) found that clients were more prone to switch audit firms the year after receiving GCM opinions.

The present study investigates companies that have remained viable for more than two years after receiving their first GCM opinions. Among the surviving companies, we follow the design of Geiger et al. (1998) and Carey et al. (2008) and examine whether clients switched auditors the year immediately subsequent the receipt of their first-time GCM opinions. Based on findings of previous studies, we hypothesize that:

H1. Companies receiving first-time GCM opinions are more likely to switch auditors than are similarly financially stressed companies that have not received GCM opinions.

Client loss related to a GCM opinion may cause revenue loss if the client is viable and thus continues to purchase auditing services from another audit firm. According to Carey et al. (2008), a negative relationship exists between GCM opinions and fees because auditors lose some clients that receive GCM opinions.

Following the design of Carey et al. (2008), we recognize that losing a client that remains viable for at least two years is a good indication of the economic cost in lost revenue to the audit firm of losing a viable client. If the analysis were based on auditor switching by companies that may fail after receiving GCM opinions, the revenue loss could not be interpreted as an economic cost since most or all of it would be lost regardless of the switching.

It must be considered that the issuance of GCM opinions is associated with higher audit fees (Francis, 1984; Francis and Simon, 1987; Davis and Ricchiute, 1993; Bell et al., 2001; Firth, 2002). This effect could partly or totally offset the effect of lost revenues due to auditor switching. We test whether auditors issuing GCM opinions 
lose a higher proportion of fees than do auditors who do not issue such opinions. Based on previous findings, we hypothesize that:

H2. The fees lost through auditor switching after the issuance of first-time GCM opinions are greater than the fees lost through auditor switching by similarly financially stressed companies that did not receive GCM opinions.

GCM opinions, client bankruptcy, and lost revenue

If GCM opinions tend to be self-fulfilling prophecies, audit firms will lose clients as an effect of their issuance of GCM opinions (Vanstraelen, 2003). This possibility has been researched with mixed evidence. Some studies have found a positive relationship between GCM opinions and client bankruptcy (Garsombke and Choi, 1992; Geiger et al., 1998; Vanstraelen, 2003), while other studies using a matched sample technique have found no such effect (Citron and Taffler, 1992; Carey et al., 2008). This persistent debate is reason to test the hypothesis in a European audit market, and we state a hypothesis in the null form as follows:

H3. Companies receiving first-time GCM opinions are not more likely to go bankrupt than are similarly financially stressed companies not receiving GCM opinions.

Bankruptcies caused by GCM opinions could lead to lost revenues to the audit firm (Carcello and Neal, 2003; Carey et al., 2008). However, this effect is likely small because most clients receiving GCM opinions are small (Carson et al., 2013) and as such pay small audit fees. Due to the contradictory previous evidence of self-fulfilling prophecies, we state the following hypothesis in the null form as well:

H4. The fees lost from companies going bankrupt following first-time GCM opinions are no greater than the fees lost from similarly financially stressed companies that have not received GCM opinions.

\section{GCM opinions, client bankruptcy, and audit firm}

In addition to the main issues addressed in the four hypotheses above, we investigate one further issue. It is debated whether large audit firms deliver higher quality than do their smaller competitors. It is claimed that big audit firms are perceived as more independent and provide higher quality audits. Examining the US and Australian markets, respectively, Geiger and Rama (2003) and Carey et al. (2008) found that Big 4 firms identify the risk of client bankruptcy better than do smaller audit firms. The ability to identify the risk of client bankruptcy is at the core of GCM opinions, and if a GCM opinion does not signal a large risk of bankruptcy, the opinion has lost its meaning. Previous research evidence of better predictive ability among Big 4 firms is in this sense evidence of higher audit quality.

Furthermore, in the aftermath of Enron, there is evidence of lower frequencies of type II errors in Big 4 firms (Big 5 at the time) than in other audit firms (Geiger et al., 2005; Geiger and Rama, 2006; Nogler, 2008), indicating that the audit models in larger audit firms have higher precision or that these firms are more interested in protecting their reputations after the Enron scandal. However, Kaplan and Williams (2012) demonstrate a changed relationship between audit firm size and GCM opinions. Contrary to the findings of most previous studies, these authors reported that Big 4 
JAAR

15,2

202 firms are less likely to issue GCM opinions to financially stressed clients than are their smaller competitors. Instead, Big 4 firms tend to be more proactive than other audit firms in terms of avoiding financially stressed clients.

Taken together, we state the fifth hypothesis in the null form due to contradictory evidence in previous studies:

H5. The increased likelihood of bankruptcy as an effect of the issuance of a GCM opinion is no stronger when the auditor represents a Big 4 firm than a non-Big 4 firm.

\section{Research method and sample selection}

We identified Swedish companies as of the fiscal year ending 2009 that had received first-time GCM opinions from their auditors that year. A total of 93 such companies were identified using a search method that reviewed over 10,000 annual and audit reports.

We examined, as did Carey et al. (2008), the full array of GCM opinions, not only the more limited type of opinion used in most previous research (Garsombke and Choi, 1992; Geiger et al., 1998; Carcello and Neal, 2003). Thus, more than one formulation could be used by the auditor to express serious concern about the future viability of the company. The analysis of $H 1$ and $H 2$ was restricted to only those companies still in operation two years after 2009.

It has been demonstrated that financially stressed companies switch auditors more frequently than do other companies (Schwartz and Menon, 1985; Krishnan and Stephens, 1995), so the tendency to switch auditors may be caused by the companies' stressful situation, regardless of the GCM opinion. To address this, a control sample was used comprising companies in financial stress that had not received GCM opinions. These companies are called non-going concern modified opinion companies (NGCM-companies), as opposed to GCM-companies. The factors used in selecting the NGCM-group correspond to the criteria used in previous research as indicators of companies in financial stress (Mutchler, 1985; Hopwood et al., 1989; Carcello and Neal, 2003; Geiger and Rama, 2003; Carey et al., 2008). In these studies, except for Carey et al. (2008), one indicator was enough to indicate financial stress. However, to ensure that this group contained only financially stressed companies, we selected the control group in accordance with Carey et al. (2008), such that all companies had negative working capital and negative net income. We used the Affärsdata database in which all annual and audit reports of Swedish companies are stored and made searchable. We found companies of comparable size (in total assets) matching all 93 GCM-companies in the same industries. The NGCM-group then contained 93 financially stressed companies, each matching a GCM company as closely as possible.

Logistic regression was applied to our pooled samples to examine the effect of first-time GCM opinions on the probability of auditor switching. We tested $H 1$ by using the following logistic regression model:

$$
\log (\text { Switching })=\mathrm{a} 0+\mathrm{a} 1 \times \mathrm{GC}+\mathrm{a} 2 \times \mathrm{BIG} 4+\mathrm{a} 3 \times \operatorname{Ln}(\mathrm{TA})+\mathrm{a} 4 \times \mathrm{PRB}
$$

where Switching $=1$ if the client subsequently switched auditors and 0 otherwise; $\mathrm{GC}=1$ if a GCM opinion was issued in 2009 and 0 otherwise; BIG4 = 1 if the auditor represents a Big 4 firm and 0 otherwise; TA is the total assets in thousands of SEK; PRB is probability of failure according to Zmijewski's (1984) model.

Table I reveals that, of the initial GCM-group, 20 companies went bankrupt during the examination period. Unless the analysis contains only companies that remain 
viable during the years after a GCM opinion, the argument that auditor switching is a cost to the audit firm as an effect of the GCM opinion is invalid. Therefore, $H 1$ and $H 2$ must be examined using a pooled sample of 73 and 89 companies that all remained viable during the two-year test period starting in 2009.

To further control for financial stress in this study, we included a measure of bankruptcy probability developed by Zmijewski (1984). For use in the logistic regression, the probability of bankruptcy (PRB) for the GCM-group was calculated using data from the annual reports on which the initial GCM opinion was issued. The PRB for the NGCM-group was calculated using financial data from the annual reports from the year the companies were selected, which is 2009 for all companies. This bankruptcy prediction model has been used in similar previous research (Wheeler et al., 1993; Carcello et al., 1995; Geiger et al., 1998; Geiger and Rama, 2003; Carey et al., 2008).

Several bankruptcy prediction models base their prognoses on liquidity, leverage, and profitability (Ohlson, 1980). The predictive abilities of various models differ only slightly, as confirmed by recent model comparisons (Lee and Choi, 2013). Even so, the control variable used here could have been chosen from alternatives such as the Black-Scholes-Merton default prediction model (Bruche and González-Aguado, 2010; Charitou et al., 2013), statistical models, and artificial intelligence. Statistical models include logit, probit, or multivariate discriminant analytical models. A model could also be constructed using neural networks (Pendharkar, 2005; Tseng and Hu, 2010), genetic algorithms (Etemadi et al., 2009), support vector machines (Yang et al., 2011), or case-based reasoning (Cho et al., 2010), but such models are not employed by accounting research because they cannot be interpreted theoretically (Carson et al., 2013). Developing an industry-specific model would provide more accurate control of the financial stress level than would general models (Tseng and Hu, 2010; Lee and Choi, 2013). However, because the bankruptcy prediction model used here serves as a control variable, in combination with other means for ensuring that the sampled firms have the same level of financial stress, and because the use of previously developed stress prediction models is generally accepted for this purpose, we adopted a pre-existing model.

Zmijewski's (1984) model is parsimonious, was developed using probit, is based on the current ratio, return on assets, and leverage ratio, and lends itself to easy data collection. For these reasons and because we sought to produce results comparable to those of Carey et al. (2008), we chose Zmijewski's bankruptcy prediction model. To ensure that our results do not depend significantly on the choice of bankruptcy prediction model, we ran a robustness test by replacing Zmijewski's (1984) PRB-value with the Altman's (1993) Z-score.

A second control variable in the model is company size (total assets). This is a relevant control variable, despite the control for size being integrated in the study's

Test group (GCM)

Control group (NGCM)

GCM-group

NGCM-group

Bankrupt companies

Sample for $H 1$ and $H 2$

Sample for H3-H5
93

20

73

93

\section{Swedish audit market}

203

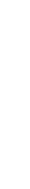 \\ $-$
}

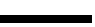


JAAR

15,2

204 design, because previous studies find that size is related to auditor switching (Haskins and Williams, 1990). A third control variable is Big 4 firm, which earns its relevance from the assumption that clients of Big 4 firms switch auditors less often due to the limited availability of comparable alternatives. Behavior in reaction to GCM opinions differs between clients of Big 4 and other audit firms (Geiger and Rama, 2006; Nogler, 2008).

The second hypothesis (H2) is tested by comparing the total fees in the year after issuance of the first-time GCM opinion between the GCM- and NGCM-groups. The relevant reference year is 2010 for both groups. Total fees include fees for both auditing and non-auditing services. Lost fees are a relevant measure of the costs to audit firms because, after auditor switching, these fees are paid to another audit firm. In line with Carey et al. (2008), we used a test of quantity proportions, a method described by Kachigan (1986, p. 186), to verify whether the lost fees differ between the GCM- and NGCM-groups.

Furthermore, to assess the possibility of self-fulfilling prophecy, due to the possible association between GCM opinion and later bankruptcy $(H 3)$, we used logistic regression on the 93 GCM-companies and the 93 NGCM-companies. Logistic regression was adopted as a method for indicating whether the probability of bankruptcy differs between the two groups. We used the following logistic regression model to detect whether issuance of GCM opinion has any impact on the probability of bankruptcy:

$$
\log (\text { Bankruptcy })=\mathrm{a} 0+\mathrm{a} 1 \times \mathrm{GC}+\mathrm{a} 2 \times \mathrm{BIG} 4+\mathrm{a} 3 \times \mathrm{Ln}(\mathrm{TA})+\mathrm{a} 4 \times \mathrm{PRB},
$$

where Bankruptcy $=1$ if the client company went bankrupt within two years of 2009 and 0 otherwise; $\mathrm{GC}=1$ if a GCM opinion was issued in 2009 and 0 otherwise; BIG4 =1 if the auditor represents a Big 4 firm and 0 otherwise; TA is the total assets in thousands of SEK; PRB is probability of failure according to Zmijewski's (1984) model.

Because there is a possibility that company size and failure may be related (Johnsen and Melicher, 1994), company size is controlled for in the regression model using the variable $\operatorname{Ln}(\mathrm{TA})$, which is the natural logarithm of total assets. In sample selection, we isolated only companies in financial stress and matched them with the test group by size, so we have double checked for the possible impact of size on the relationship between GCM opinion and bankruptcy. Thus, the possible impact of size differences should have been eliminated. Furthermore, due to the possibility of bias in the material relating to other relevant factors that may differ between the GCM- and NGCM-groups, Zmijewski's probability of bankruptcy measure was controlled for. With this measure, any difference between the groups concerning the variables measured by Zmijewski's formula is controlled for and not allowed to affect the result, reducing the risk of false attribution of a difference between the GCM opinion and NGCM bankruptcy probabilities to the issuance of GCM opinions.

Morris and Strawser (1999) found that Big 4 firm (Big 5 at that time) issuance of GCM opinions more strongly affected bank closure than did issuance of corresponding GCM opinions by other audit firms. Therefore, Big 4 firm is controlled for in the regression model. We wanted to ensure that no such bias between the GCMand the NGCM-groups could distort the results.

The hypothesis regarding the possible self-fulfilling prophecy effect on the fees lost (H4) was tested by comparing the GCM- and NGCM-groups in terms of total fees lost. Total fees lost were identified by assessing how much was paid during the last year before client failure. 
Finally, we investigated the possibility that Big 4 firms may have a moral impact on stakeholders by testing $H 5$ using a modified version of the above logistic regression formula. We regressed: $\log ($ Bankruptcy $)=\mathrm{a} 0+\mathrm{a} 1 \times \mathrm{GC}+\mathrm{a} 2 \times \mathrm{BIG} 4+\mathrm{a} 3 \times \operatorname{Ln}(\mathrm{TA})+$ $\mathrm{a} 4 \times \mathrm{PRB}+\mathrm{a} 5 \times \mathrm{GC} \times \mathrm{BIG} 4$, in which the last term is the product of the GCM opinion and Big 4 variables, as a way of detecting an interaction effect between GCM opinions and Big 4 firms on client bankruptcy.

\section{Results}

Demographic data

Table II presents demographic data on the two sample groups, and indicates that the GCM- and NGCM-groups are similar in size, level of financial stress (measured by bankruptcy probability, PRB), Big 4 firm auditors, and total fees paid to the audit firms. These aggregated results indicate that the matching process, though not perfect, effectively paired GCM- and NGCM-cases in an attempt to produce two groups of similar-sized companies subject to similar financial stress.

\section{GCM opinions, auditor switching, and lost revenue}

Table III shows that 12 of the 73 companies (16.4 percent) that had received GCM opinions and remained viable switched auditors within one year, and that four of the 89 viable NGCM-companies (4.5 percent) switched auditors. The difference between the GCM-group and the NGCM-group in terms of auditor switching was statistically significant $(p=0.011)$.

The switching rate for the NGCM-group was lower than the corresponding rates presented in Geiger et al. (1998) and Carey et al. (2008), which both reported switching rates of 8-10 percent. However, their sampled companies were much larger than those in the current sample, which may explain the switching rate differences. Hence, the lower switching rate among the NGCM-companies observed here can be explained by the more limited management resources and auditing knowledge possessed by very small companies. Managers of such companies cannot normally question the objectivity and nuances of auditor judgments, may be more reluctant to criticize auditors, and, by extension, may be more reluctant to replace auditors.

\begin{tabular}{lccc}
\hline Variable & GCM sample & NGCM sample & p-value for diff \\
\hline Log of total assets (LNTA) & 5.82 & 5.90 & \\
Bankruptcy probability (PRB) & 0.38 & 0.13 & 0.003 \\
Big 4 audit firm (\%) & 48 & 52 & 0.013 \\
Total fees (SEK) $^{\mathrm{a}}$ & 22,156 & 24,732 & 0.354 \\
\end{tabular}

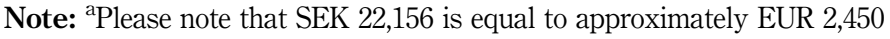

\section{Swedish audit market}

205

\begin{tabular}{|c|c|c|c|c|}
\hline \multicolumn{5}{|c|}{ Auditor switching } \\
\hline GCM opinion & Yes & No & Total & \\
\hline $\begin{array}{l}\text { Yes } \\
\text { No }\end{array}$ & $\begin{array}{c}12(16.4 \%) \\
4(4.5 \%)\end{array}$ & $\begin{array}{l}61(83.6 \%) \\
85(95.5 \%)\end{array}$ & $\begin{array}{l}73 \\
89\end{array}$ & $\begin{array}{l}\text { Table III. } \\
\text { Switching rates for the }\end{array}$ \\
\hline \multicolumn{4}{|c|}{ Notes: $\chi^{2}=6.4 ; \mathrm{df}=1 ; p=0.011$} & GCM- and NGCM-groups \\
\hline
\end{tabular}

Table II. Demographic data, means 
JAAR

15,2

206
Table IV presents the results of our logistic regression examining auditor switching by subsequently viable companies as a function of various variables. The model is significant $(p<0.05)$ and reveals relationships between the variable Switching and one of the independent variables, GC $(p=0.027)$. Hence, the logistic regression supports $H 1$, finding a positive and significant relationship between the issuance of a first-time GCM opinion and auditor switching.

$\operatorname{Ln}(\mathrm{TA})$, the logarithm of total assets, capturing client size, is positive and nearly significant at the 5 percent level, providing some indication that slightly larger companies are more likely to switch auditors. The relationship with size is contrary to the results of previous studies (Francis and Wilson, 1988; McKeown et al., 1991; Geiger et al., 1998; Carey et al., 2008); however, these studies sampled companies in a totally different size class from that sampled here. Again, in our sample, the smallest companies may not be as ready to take action and change their auditors as are slightly larger firms. We find no evidence for any relationship between Big 4 firm and auditor switching.

To address $H 2$, concerning the fees lost as a result of auditor switching, we aggregated all subsequent-year fees paid by the viable GCM- and NGCM-companies. The results of this aggregation are presented in Table V. The 12 companies that switched auditors in 2010 after receiving GCM opinions paid total fees of SEK 311,431 to their new audit firms that year, and the 61 clients that remained with their current auditors paid SEK 1,146,054. These figures should be compared with SEK 90,059 for the four companies that switched audit firms in the NGCM-group and SEK 2,111,853 for the NGCM-companies that continued with their current audit firms. Test statistics

\begin{tabular}{lrc}
\hline Variable & Coefficient & $p$-value \\
\hline Constant & & \\
GC & -8.267 & 0.006 \\
BIG4 & 1.385 & 0.027 \\
Ln(TA) & -0.650 & 0.321 \\
PRB & 0.909 & 0.052 \\
P & -0.026 & 0.565
\end{tabular}

Notes: Model: $\log ($ Switching $)=\mathrm{a} 0+\mathrm{a} 1 \times \mathrm{GC}+\mathrm{a} 2 \times \mathrm{BIG} 4+\mathrm{a} 3 \times \operatorname{Ln}(\mathrm{TA})+\mathrm{a} 4 \times$ PRB . Model values: $p=0.011$; Pseudo $R^{2}=16.4$ percent. Switching $=1$ if the client subsequently switched auditors and 0 otherwise; $\mathrm{GC}=1$ if a GCM opinion was issued in 2009 and 0 otherwise; BIG4 $=1$ if the auditor represents a Big 4 firm and 0 otherwise; TA, total assets in thousands of SEK; PRB, probability of failure according to Zmijewski's (1984) model
Table IV.

Logistic regression parameters for the auditor switching test 
of quantity proportions reveals a significant difference $(p<0.001)$ in the lost fees between the groups, supporting H2. Auditors of GCM-companies lose a higher proportion of their fees than do auditors of NGCM-companies due to the issuance of GCM opinions.

GCM opinions, client bankruptcy, and lost revenue

We addressed the self-fulfilling prophecy issue in the Swedish audit market for small client companies by first examining the bankruptcy proportions of GCM-companies and equally financially stressed NGCM-companies. Table VI presents the numbers and percentages of companies that failed within two years of the GCM opinions, and the corresponding figures for the NGCM-companies. In total, 20 of the 93 GCM-companies (21.5 percent) failed within two years, while only four of the 93 NGCM-companies (4.3 percent) failed during the same period. This difference is statistically significant $(p=0.001)$. These proportions are more comparable to the US results of Geiger et al. (1998), who found 18.9 percent failure in the GCM-group and 5.6 percent failure in the NGCM-group, than to the Australian data reported by Carey et al. (2008), who found 11.8 percent failure in the GCM-group and 10.3 percent failure in the NGCM-group.

Again, as a way of controlling for bankruptcy-related factors, a multiple regression was computed using bankruptcy as the dependent variable. As reported in Table VII, the total model is significant $(p<0.05)$ and the results are in line with those reported above regarding the higher probability of bankruptcy in the GCM-group. Specifically, the variable $\mathrm{GC}$ has a positive coefficient that is significant $(p=0.001)$. For this reason, we find evidence for a relationship between the probability of company failure and the issuance of first-time GCM opinions. In contrast to what was expected in $H 3$, there is support for the idea of a self-fulfilling prophecy effect in this sample of small Swedish

\begin{tabular}{lcc}
\hline GCM opinion & Bankrupt & Viable \\
\hline Yes & $20(21.5 \%)$ & $73(78.5 \%)$ \\
No & $4(4.3 \%)$ & $89(95.7 \%)$
\end{tabular}

Notes: $\chi^{2}=12.247 ; \mathrm{df}=1 ; p=0.001$

\section{Swedish audit market}

207 
JAAR

15,2

208 companies. The present result is in contrast to the findings of Citron and Taffler (1992), who could not verify a self-fulfilling prophecy effect, and to the findings of Carey et al. (2008), who reported no self-fulfilling prophecy in their sample of Australian companies. However, our result corresponds to those of Garsombke and Choi (1992) and Geiger and Rama (2003), who reported significantly higher failure rates in the USA for GCM- than NGCM-companies.

The logistic regression model presented in Table VII produced mixed results for the control variables. Size is significantly related to bankruptcy filing $(p=0.020)$ such that larger companies are less likely to fail than are smaller companies. The negative relationship between size and bankruptcy does not support the finding of Carey et al. (2008), who reported the opposite sign for the relationship. Carey et al. (2008) sampled substantially larger companies than we did, leading to the conclusion that very small companies may behave differently from very large companies in this respect. There is an indication of a positive relationship between Big 4 firm and business failure $(p=0.087)$, but the relationship is not significant at the 5 percent level. The PRB-value, indicating the statistical probability of bankruptcy before its occurrence, is not significantly related to the actual filing of bankruptcy for this sample. This result agrees with those of Geiger and Rama (2003) and Carey et al. (2008), none of whom reported a significant relationship with the PRB-factor.

The present study further assesses fees lost due to bankruptcy by aggregating the fees paid to audit firms in 2009. Table VIII indicates that the group of 20 companies receiving first-time GCM opinions and then going bankrupt paid total fees of SEK 602,979 to their audit firms, while the surviving 73 companies paid total fees of SEK 1,457,485. These amounts can be compared with those paid by the four NGCM-companies that went bankrupt and paid SEK 98,172 in total fees and the 89 NGCM-companies that remained viable and paid SEK 2,201,912 in total fees. The test of quantity proportions reveals that the proportion of fees lost through the 20 GCM-companies that later went bankrupt is significantly higher $(p<0.001)$ than the proportion lost through the four NGCM-companies that went bankrupt. Thus, for the sample of small Swedish companies in financial stress, a first-time GCM opinion increases the auditors' lost fees, which is in contrast to $H 4$.

A final test of the fees lost as a function of the issuance of first-time GCM opinions is to combine the effects of auditor switching and bankruptcies. We computed this effect for our sample and found that a significantly higher proportion of lost fees occur in the GCM- than the NGCM-group $(p<0.001)$. We conclude, partly confirming and partly extending the results of Carey et al. (2008), that auditors issuing first-time GCM opinions are burdened with higher lost fees from losing clients than are auditors not issuing GCM opinions to their financially stressed clients.

\begin{tabular}{lcc}
\hline & Test group $(\mathrm{GCM})$ & Control group (NGCM) \\
\hline & & \\
Bankruptcy & $602,979(n=20)$ & $98,172(n=4)$ \\
Viable & $1,457,485(n=73)$ & $2,201,912(n=89)$ \\
Total fees & $2,060,464$ & $2,300,084$ \\
Mean & 22,156 & 24,732 \\
SD & 23,754 & 25,301
\end{tabular}

Notes: $Z=4.56 ; p<0.001$
Fees lost (SEK) due to client bankruptcy 
GCM opinions, client bankruptcy, and audit firm

By including the interaction between Big 4 and GC as a term in the regression formula, we tested $H 5$, that the self-fulfilling prophecy effect is no stronger for Big 4 firms than for other audit firms. The interaction term is insignificant and we find support for $H 5$, suggesting that the GCM opinions issued by Big 4 firms are no more harmful to clients than are those issued by other audit firms. This indicates that if there is a difference in perceived audit quality between Big 4 and other audit firms, the effect is not sufficient to alter the self-fulfilling prophecy effect. Thus, the higher audit quality detected in Big 4 firms (Geiger and Rama, 2006; Nogler, 2008) does not affect the self-fulfilling prophecy effect.

\section{Alternate financial stress control variables}

Finally, to ensure that our results are robust with respect to our choice of Zmijewski's (1984) model as control variable for financial stress level, we reran our tests replacing PRB with Altman's (1993) Z-score, used in previous studies to control for financial stress (Blay et al., 2011). Replacing PRB with the $Z$-score did not change the results of the regressions.

\section{Discussion and conclusions}

Previous research has examined companies that switch auditors, using audit report outcome as an explanatory variable. With few exceptions, however, those studies have not used the first-time GCM opinion as an explanatory variable for the costs in terms of revenue lost to the audit firm. The few previous results support the contention that financial dependence is inherent in the relationship between auditors and large clients. Empirical results from the USA indicate a positive relationship between first-time GCM opinions and auditor switching (Geiger et al., 1998; Carcello and Neal, 2003), but provide mixed evidence as to the self-fulfilling prophecy effect with respect to the association between GCM opinions and bankruptcy. Australian evidence (Carey et al., 2008) provides support for a positive relationship between GCM opinions and auditor switching, and suggests that GCM opinions are associated with higher fee loss due to auditor switching, but does not support a self-fulfilling prophecy effect. Our study contributes to the literature by extending previous work to a population of first-time GCM opinions in Europe, specifically Sweden, and to a population of small companies as opposed to the large companies constituting the samples in previous research. We assess fees lost to the auditors as a direct measure of the cost of GCM opinions.

We found evidence that the issuance of first-time GCM opinions to small companies is positively related to auditor switching, confirming the finding of Carey et al. (2008). We also found evidence for higher failure rates among companies receiving first-time GCM opinions than among equally financially stressed companies that do not receive GCM opinions. This demonstrates a self-fulfilling prophecy effect of GCM opinions for small companies in Sweden. This result is in contrast to that of Carey et al. (2008), but in line with those of other studies (e.g. Vanstraelen, 2003).

We also found that auditors issuing first-time GCM opinions lose proportionally more fees due to both auditor switching and client bankruptcy than do auditors who do not issue GCM opinions. These results confirm the findings of Carey et al. (2008).

Whether auditor judgments and behaviors are actually affected by the increased frequency of auditor switching after issuance of GCM opinions remains to be explored, but this study indicates that the results of previous research into large clients may be
209 
JAAR

15,2

210 extended to small clients. The revenues of audit firms are, at least from a short-term perspective, adversely affected by their issuance of GCM opinions to small clients.

We recognize a limitation of this study regarding the choice of control companies. The NGCM-companies should be financially stressed companies that have not received GCM opinions, and the level of financial stress in the test group should be identical to that in the control group. We attempted to find similarly sized and similarly financially stressed companies from the same industries as those companies in the test group (the GCM-group) and we controlled for differences between the two groups using a measure of bankruptcy probability developed by Zmijewski (1984). We also tested the robustness of this method of controlling for differences in financial stress between the two groups by replacing Zmijewski's (1984) financial stress prediction with the corresponding prediction using Altman's (1993) Z-score in the regressions, arriving at the same result. Still, we may have missed other variables relevant to auditor switching or client bankruptcy.

The present study also contributes to research into auditor difficulties in estimating financial risk in European reporting environments. In this study, almost 80 percent of the financially stressed companies receiving first-time GCM opinions remained viable two years after receiving the GCM opinions. Thus, we confirm auditors' apparent difficulties in identifying the risk of client bankruptcy and underline the need for further research and more formalized methods of making going concern judgments.

\section{References}

Altman, E.I. (1993), Corporate Financial Distress and Bankruptcy: A Complete Guide to Predicting and Avoiding Distress and Profiting from Bankruptcy, Wiley, New York, NY.

Arnold, V., Collier, P.A., Leech, S.A. and Sutton, S.G. (2001), "The impact of political pressure on novice decision makers: are auditors qualified to make going-concern judgements?", Critical Perspectives on Accounting, Vol. 12 No. 3, pp. 323-338.

Bamber, E.M. and Iyer, V.M. (2007), "Auditors' identification with their clients and its effect on auditors' objectivity”, Auditing: A Journal of Practice \& Theory, Vol. 26 No. 2, pp. 1-24.

Bell, T.B., Landsman, W.R. and Shackelford, D.A. (2001), “Auditors' perceived business risk and audit fees: analysis and evidence", Journal of Accounting Research, Vol. 39 No. 1, pp. 35-43.

Blay, A.D. and Geiger, M.A. (2013), "Auditor fees and auditor independence: evidence from going-concern reporting decisions", Contemporary Accounting Research, Vol. 30 No. 2, pp. 579-606.

Blay, A.D., Geiger, M.A. and North, D.S. (2011), "The auditor's going-concern opinion as a communication of risk", Auditing: A Journal of Practice \& Theory, Vol. 30 No. 2, pp. 77-102.

Bruche, M. and González-Aguado, C. (2010), "Recovery rates, default probabilities, and the credit cycle", Journal of Banking and Finance, Vol. 34 No. 4, pp. 754-764.

Carcello, J.V. and Neal, T.L. (2003), "Audit committee characteristics and auditor dismissals following 'new' going-concern reports”, The Accounting Review, Vol. 78 No. 1, pp. 95-118.

Carcello, J.V., Hermanson, D. and Huss, F. (1995), "Temporal changes in bankruptcy-related reporting", Auditing: A Journal of Practice \& Theory, Vol. 14 No. 2, pp. 133-143.

Carey, P.J., Geiger, M.A. and O'Connell, B.T. (2008), "Costs associated with goingconcern-modified audit opinions: an analysis of the Australian audit market", Abacus, Vol. 44 No. 1, pp. 61-81. 
Carson, E., Fargher, N.L., Geiger, M.A., Lennox, C.S., Raghunandan, K. and Willekens, M. (2013), "Auditor reporting for going-concern uncertainties: a research synthesis", Auditing: A Journal of Practice \& Theory, Vol. 32 No. S1, pp. 353-384.

Chen, K.C.W. and Church, B.K. (1992), "Default on debt obligations and the issuance of goingconcern opinions", Auditing: A Journal of Practice \& Theory, Vol. 11 No. 2, pp. 30-49.

Charitou, A., Dionysiou, D., Lambertides, N. and Trigeorgis, L. (2013), “Alternative bankruptcy prediction models using option-pricing theory", Journal of Banking and Finance, Vol. 37 No. 7, pp. 2329-2341.

Cho, S., Hong, H. and Ha, B.C. (2010), "A hybrid approach based on the combination of variable selection using decision trees and case-based reasoning using the Mahalanobis distance: for bankruptcy prediction”, Expert Systems with Applications, Vol. 37 No. 4, pp. 3482-3488.

Citron, D.B. and Taffler, R.J. (1992), "The audit report under going-concern uncertainties: an empirical analysis", Accounting and Business Research, Vol. 22 No. 88, pp. 337-345.

Craswell, A. (1988), "The association between qualified opinions and auditor switches", Accounting and Business Research, Vol. 19 No. 73, pp. 23-31.

Davis, L.R. and Ricchiute, N. (1993), "Audit effort, audit fees, and the provision of non-audit services to audit clients", The Accounting Review, Vol. 68 No. 1, pp. 135-150.

DeFond, M.L. (1992), "The association between changes in client firm agency costs and auditor switching", Auditing: A Journal of Practice \& Theory, Vol. 11 No. 1, pp. 16-31.

Etemadi, H., Rostamy, A.A.A. and Dehkordi, H.F. (2009), "A genetic programming model for bankruptcy prediction: empirical evidence from Iran", Expert Systems with Applications, Vol. 36 No. 2, pp. 3199-3207.

Firth, M. (2002), "Auditor-provided consultancy services and their associations with audit fees and audit opinions", Journal of Business, Finance and Accounting, Vol. 29 Nos 5/6, pp. $661-700$.

Francis, J. (1984), "The effect of audit firm size on audit prices: a study of the Australian market", Journal of Accounting and Economics, Vol. 6 No. 2, pp. 133-151.

Francis, J. and Simon, D. (1987), "A test of audit pricing in the small-client segment of the US audit market”, The Accounting Review, Vol. 62 No. 1, pp. 145-157.

Francis, J. and Wilson, E.R. (1988), "Auditor changes: a joint test of theories relating to agency costs and auditor differentiations", The Accounting Review, Vol. 63 No. 4, pp. 663-682.

Garsombke, H.P. and Choi, S. (1992), “The association between auditors' uncertainty opinions and business failures", Advances in Accounting, Vol. 10, pp. 45-60.

Geiger, M.A. and Raghunandan, K. (2002), "Auditor tenure and audit reporting failures", Auditing: A Journal of Practice \& Theory, Vol. 21 No. 1, pp. 67-79.

Geiger, M.A. and Rama, D.V. (2003), "Audit fees, non-audit fees, and auditor reporting on stressed companies", Auditing: A Journal of Practice \& Theory, Vol. 22 No. 2, pp. 53-69.

Geiger, M.A. and Rama, D.V. (2006), “Audit firm size and going-concern reporting accuracy”, Accounting Horizons, Vol. 20 No. 1, pp. 1-17.

Geiger, M.A., Raghunandan, K. and Rama, D.V. (1998), "Cost associated with going-concernmodified audit opinions: an analysis of auditor changes, subsequent opinions, and client failures", Advances in Accounting, Vol. 16, pp. 117-139.

Geiger, M.A., Raghunandan, K. and Rama, D.V. (2005), "Recent changes in the association between bankruptcies and prior audit opinions", Auditing: A Journal of Practice \& Theory, Vol. 24 No. 1, pp. 21-35.

Haskins, M.E. and Williams, D.D. (1990), “A contingent model of intra-big eight auditor changes", Auditing: A Journal of Practice \& Theory, Vol. 9 No. 3, pp. 55-74. 
JAAR

15,2
Herbohn, K., Ragunathan, V. and Garsden, R. (2007), "The horse has bolted: revisiting the market reaction to going-concern modifications of audit reports", Accounting and Finance, Vol. 47 No. 3, pp. 473-493.

Hopwood, W., McKeown, J. and Mutchler, J. (1989), “A test of the incremental explanatory power of opinions qualified for consistency and uncertainty", The Accounting Review, Vol. 64 No. 1, pp. 28-59.

Humphrey, C. (2008), "Auditing research: a review across the disciplinary divide", Accounting, Auditing \& Accountability Journal, Vol. 21 No. 2, pp. 170-203.

Johnsen, T. and Melicher, R.W. (1994), "Predicting corporate bankruptcy and financial distress: information value added by multinational logit models", Journal of Economics and Business, Vol. 64 No. 4, pp. 269-286.

Johnson, W.B. and Lys, T. (1990), “The market for audit services: evidence from voluntary auditor changes", Journal of Accounting and Economics, Vol. 12 Nos 1/3, pp. 281-308.

Kachigan, S.K. (1986), Statistical Analysis, Radius Press, New York, NY.

Kaplan, S. and Williams, D. (2012), "The changing relationship between audit firm size and going-concern reporting", Accounting, Organizations and Society, Vol. 37 No. 5, pp. 322-341.

Kida, T. (1980), "An investigation into auditors' continuity and related qualification judgments”, Journal of Accounting Research, Vol. 18 No. 2, pp. 506-523.

Knechel, W.R. and Vanstraelen, A. (2007), "The relationship between auditor tenure and audit report quality implied by going-concern opinions", Auditing: A Journal of Practice \& Theory, Vol. 26 No. 1, pp. 113-131.

Krishnan, J. (1994), “Auditor switching and conservatism”, The Accounting Review, Vol. 69 No. 1, pp. 200-215.

Krishnan, J. and Stephens, R. (1995), "Evidence on opinion shopping from audit opinion conservatism”, Journal of Accounting and Public Policy, Vol. 14 No. 3, pp. 179-201.

Krishnan, J., Krishnan, J. and Stephens, R.G. (1996), “The simultaneous relation between auditor switching and audit opinion: an empirical analysis", Accounting and Business Research, Vol. 26 No. 3, pp. 224-236.

Lee, S. and Choi, W.S. (2013), "A multi-industry bankruptcy prediction model using back-propagation neural network and multivariate discriminant analysis", Expert Systems with Applications, Vol. 40 No. 8, pp. 2941-2946.

Lennox, C. (2000), "Do companies successfully engage in opinion-shopping? Evidence from the UK", Journal of Accounting and Economics, Vol. 29 No. 3, pp. 321-337.

Louwers, T.J., Messina, F.M. and Richard, M.D. (1999), "The auditor's going-concern modification as a self-fulfilling prophecy: a discrete-time survival analysis”, Decision Sciences, Vol. 30 No. 3, pp. 805-824.

McKeown, J.C., Mutchler, J. and Hopwood, W. (1991), "Towards an explanation of auditor failure to modify the audit opinion of bankrupt companies", Auditing: A Journal of Practice \& Theory, Vol. 10 No. 1, pp. 1-13.

Menon, K. and Schwartz, K.B. (1987), "An investigation of audit qualification decisions in the presence of going-concern uncertainties”, Contemporary Accounting Research, Vol. 3 No. 2, pp. 302-315.

Menon, K. and Williams, D.D. (2010), "Investor reaction to going-concern audit reports", The Accounting Review, Vol. 85 No. 6, pp. 2075-2106.

Morris, R.E. and Strawser, J.R. (1999), "An examination of the effect of CPA firm type on bank regulators' closure decisions”, Auditing: A Journal of Practice \& Theory, Vol. 18 No. 2, pp. $143-158$. 
Mutchler, J. (1984), “Auditor's perceptions of the going-concern opinion”, Auditing: A Journal of Practice \& Theory, Vol. 3 No. 2, pp. 17-30.

Mutchler, J. (1985), “A multivariate analysis of the auditor's going-concern opinion decision", Journal of Accounting Research, Vol. 23 No. 2, pp. 668-682.

Mutchler, J. and Williams, D.D. (1990), "The relationship between audit technology, client risk profiles, and the going-concern opinion decision", Auditing: A Journal of Practice \& Theory, Vol. 9 No. 3, pp. 39-54.

Mutchler, J., Hopwood, W. and McKeown, J.C. (1997), "The influence of contrary information and mitigating factors on audit opinion decisions on bankrupt companies", Journal of Accounting Research, Vol. 35 No. 2, pp. 295-310.

Nogler, G.E. (1995), “The resolution of auditor going-concern opinions”, Auditing: A Journal of Practice \& Theory, Vol. 14 No. 2, pp. 54-73.

Nogler, G.E. (2004), "Long-term effects of the going-concern opinion”, Managerial Auditing Journal, Vol. 19 No. 5, pp. 681-690.

Nogler, G.E. (2008), "Going-concern modifications, CPA firm size, and the Enron effect", Managerial Auditing Journal, Vol. 23 No. 1, pp. 51-67.

Ohlson, J. (1980), "Financial ratios and the probabilistic prediction of bankruptcy", Journal of Accounting Research, Vol. 18 No. 1, pp. 109-131.

Pendharkar, P.C. (2005), "A threshold-varying artificial neural network approach for classification and its application to bankruptcy prediction problem", Computers \& Operations Research, Vol. 32 No. 10, pp. 2561-2582.

Rosman, A.J. (2011), “Auditors' going-concern judgments: rigid, adaptive, or both?”, Review of Accounting and Finance, Vol. 10 No. 1, pp. 30-45.

Ruiz-Barbadillo, E., Gómez-Aguilar, N., de Fuentes-Barbará, C. and García-Benau, M.A. (2004), "Audit quality and going-concern decision-making process: Spanish evidence", European Accounting Review, Vol. 13 No. 4, pp. 597-620.

Schwartz, K.B. and Menon, K. (1985), “Auditor switches by failing firms”, The Accounting Review, Vol. 60 No. 2, pp. 248-261.

Tseng, F.M. and Hu, Y.C. (2010), "Comparing four bankruptcy prediction models: logit, quadratic interval logit, neural and fuzzy neural networks", Expert Systems with Applications, Vol. 37 No. 3, pp. 1846-1853.

Tucker, R.R., Matsumura, E.M. and Subramanyam, K.R. (2003), "Going-concern judgements: an experimental test of the self-fulfilling prophecy and forecast accuracy", Journal of Accounting \& Public Policy, Vol. 22 No. 5, pp. 401-432.

Umar, A. and Anandarajan, A. (2004), "Dimensions of pressures faced by auditors and its impact on auditors' independence: a comparative study of the USA and Australia", Managerial Auditing Journal, Vol. 19 No. 1, pp. 99-116.

Van Peursem, K.A. and Pratt, M.J. (2002), "A New Zealand failure prediction model: development and international implications", Advances in International Accounting, Vol. 15, pp. 229-247.

Van Peursem, K.A., Locke, J. and Harnisch, N. (2005), “Going-concern guidance for New Zealand auditors: transitions in communicative acts", Critical Perspectives on Accounting, Vol. 17 No. 1, pp. 109-137.

Vanstraelen, A. (1999), "The auditor's going-concern opinion decision: a pilot study", International Journal of Auditing, Vol. 3 No. 1, pp. 41-57.

Vanstraelen, A. (2003), "Going-concern opinions, auditor switching, and the self-fulfilling prophecy effect examined in the regulatory context of Belgium", Journal of Accounting Auditing and Finance, Vol. 18 No. 2, pp. 231-253.

\section{Swedish audit market}

. 
JAAR

15,2

214
Wheeler, S., Pany, K. and Chewning, E. (1993), "Inter-firm differences in propensities to modify audit opinions for pre-SAS No. 58 accounting principles changes", Accounting Horizons, Vol. 7 No. 3, pp. 46-54.

Yang, Z., You, W. and Guoli Ji, G. (2011), "Using partial least squares and support vector machines for bankruptcy prediction”, Expert Systems with Applications, Vol. 38 No. 7, pp. 8336-8342.

Ye, P., Carson, E. and Simnett, R. (2011), "Threats to auditor independence: the impact of relationship and economic bonds", A Journal of Practice \& Theory, Vol. 30 No. 1, pp. 121-148.

Zmijewski, M.E. (1984), "Methodological issues related to the estimation of financial distress prediction models", Journal of Accounting Research, Vol. 22, pp. 59-82.

\section{Corresponding author}

Dr Jan Svanberg can be contacted at: jan.svanberg@miun.se

To purchase reprints of this article please e-mail: reprints@emeraldinsight.com Or visit our web site for further details: www.emeraldinsight.com/reprints 